\title{
The Trend to Discriminate Christians: Shifting from the 'Post-Christian' West to the Global South
}

\author{
Nataliya S. Semenova ${ }^{1, *(D)}$, Ekaterina V. Kiseleva ${ }^{2}(\mathbb{D})$ and Aleksandr M. Solntsev ${ }^{2}(\mathbb{D}$ \\ 1 Church Practical Department, Moscow Theological Academy, The Holy Trinity—St. Sergius Lavra, \\ Sergiev Posad, 141300 Moscow, Russia \\ 2 Department of International Law, Peoples' Friendship University of Russia (RUDN University), \\ 117198 Moscow, Russia; kiseleva-ev@rudn.ru (E.V.K.); solntsev-am@rudn.ru (A.M.S.) \\ * Correspondence: semenovanataliya@mail.ru
}

Citation: Semenova, Nataliya S., Ekaterina V. Kiseleva, and Aleksandr M. Solntsev. 2021. The Trend to Discriminate Christians: Shifting from the 'Post-Christian' West to the Global South. Religions 12: 108. https://doi.org/10.3390/rel12020108

Academic Editor: Waheeda Amien

Received: 30 December 2020

Accepted: 29 January 2021

Published: 6 February 2021

Publisher's Note: MDPI stays neutral with regard to jurisdictional claims in published maps and institutional affiliations.

Copyright: (c) 2021 by the authors. Licensee MDPI, Basel, Switzerland. This article is an open access article distributed under the terms and conditions of the Creative Commons Attribution (CC BY) license (https:// creativecommons.org/licenses/by/ $4.0 /)$.

\begin{abstract}
To date, various international treaties have been adopted at the universal and regional levels, guaranteeing the protection of every person's freedom of conscience and religion. Moreover, international monitoring mechanisms have been established to protect this human freedom within the framework of the UN, as well as various regional organizations (OSCE, Council of Europe, African Union). (1) In this article, the authors analyze these mechanisms and identify both positive practices and negative discriminatory practices against Christians - citizens of the states of the Global South. (2) The methodological basis of the study involves a combination of general scientific (dialectical, historical, inductive, deductive, analytical, synthetic) and particular scientific methods (formal-legal, comparative-legal, interpretative, statistical, procedural, and dynamic). (3) The use of these allowed the authors to identify a number of key problems in the indicated discourse and to draw conclusions. With regard to abortion, the authors conclude that current trend is that, in multiple and various ways, states are pressed to prioritize a woman's right to life, a woman's freedom of "reproductive choice" over a doctor's right to freedom of conscience. The situation is similar with the prioritization of the so-called "rights" of LGBT persons in relation to the rights of believing Christians. Moreover, the authors pay much attention to the analysis of the situation of the prosecution and persecution of Christians in the countries of the Global South, especially in Africa. (4) In conclusion, it is noted that various instruments, both political and legal, have been established in international law which make it possible to identify facts of the violation of freedom of religion and call to account for such acts of discrimination, but they are not always effective.
\end{abstract}

Keywords: international law; human rights; discrimination; Christianophobia; freedom of conscience; freedom of religion; abortion; UN; OSCE

\section{Introduction}

On 22 August 2019, the United Nations celebrated the first annual International Day Commemorating the Victims of Acts of Violence Based on Religion or Belief. The establishment of such an international day testifies to a serious problem with respect to human rights, primarily the right to freedom of thought, conscience, and religion, in various countries.

"According to the Organization for Security and Cooperation in Europe (OSCE), [E]very 5 min a Christian is killed for their faith ... More than 100 million Christians are being persecuted today ... These figures should make the international community not only think and talk about the problem of discrimination against Christians, but also take decisive action in their defense". ${ }^{1}$

1 Combating discrimination against Christians in the world as a contribution to the development of the concept of human rights. Speech by the Chairman of the DECR, Metropolitan Hilarion of Volokolamsk at a meeting of the III UN Committee (New York, 23 October 2012). Available online: https:/ / pravoslavie.ru/56968.html (accessed on 20 December 2020). 
For the period 1945 to 2019, an independent branch was formed within the framework of international law-international human rights law. One of the basic principles of international law on which this branch is based is "respect for human rights and fundamental freedoms, including freedom of thought, conscience and religion". ${ }^{2}$ This principle is a peremptory norm of $j u s$ cogens, the violation of which is unacceptable. It is important to pay attention to the fact that it is the freedom of thought, conscience, and religion that is especially highlighted within the framework of this principle and even included in its name.

Moreover, states have committed themselves to respecting the right to freedom of thought, conscience, and religion in the framework of numerous international treaties, which were based on the Universal Declaration of Human Rights of 1948 (Articles 18, 19, 20). The basic universal international treaty that enshrines the right to freedom of thought, conscience, and religion is the International Covenant on Civil and Political Rights of 1966 (Articles 18, 19, 20, 26, 27), as well as the International Covenant on Economic, Social and Cultural Rights of 1966 (para. 3, Article 13).

At the regional level, international treaties have also been adopted that consolidate and detail the right to freedom of thought, conscience, and religion, taking into account local cultural characteristics. In addition, all international human rights treaties contain provisions prohibiting discrimination based on religious attitudes.

Thus, it can be stated that, at the international level, there is a solid legal basis for international obligations of states to guarantee the right to freedom of conscience, thought, and religion. It should also be noted that compliance with these guarantees is ensured at the international universal level by the existence of a developed system of statutory and contractual control mechanisms, within the framework of which states report on the fulfillment of their obligations.

Nevertheless, despite the existence of a well-developed international legal system for protecting the right to freedom of thought, conscience, and religion, the problem of the implementation of this right, including persecution and discrimination based on religion, is acute in many countries of the world.

As stated by Konstantin Dolgov, commissioner of the Ministry of Foreign Affairs of the Russian Federation for Human Rights, Democracy and the Rule of Law,

In recent years, despite the measures taken by the states, the OSCE area has seen a serious increase in intolerance on religious grounds towards Jews, Muslims and especially Christians. Christianity, its shrines and followers are subjected to prosecution, violence, persecution, discrimination ... Among such manifestations are attacks on clergy, opposition to religious events, destruction and desecration of Christian churches and cemeteries, attempts to remove religious symbols from public places, infringement of the freedom of expression of Christians, discrimination in economic life and other spheres. The number of acts of vandalism, arson, theft of Christian values and cultural heritage is on the rise. ${ }^{3}$

For the past 10 years, the Russian Orthodox Church has constantly drawn the attention of the international community to the problem of the persecution and discrimination of Christians.

It should be noted that the term "Christianophobia" has come into widespread international use since it was first voiced at the 2009 UN World Conference against Racism, where the participating states regretfully noted the global rise in the number of incidents of racial or religious intolerance and violence, including Christianophobia. ${ }^{4}$

2 Final Act of the Conference on Security and Cooperation in Europe 1975. Available online: https:/ / www.osce.org/helsinki-final-act (accessed on 20 December 2020).

3 The Foreign Ministry Announced the Surge of Christianophobia in the West. Available online: https://www.interfax.ru/russia/511239 (accessed on 20 December 2020).

4 Clause 12 of the Outcome Document of the Durban Review Conference (2009), United against Racism, Racial Discrimination, Xenophobia and Related Intolerance New York, 2012, p. 96. Available online: https://www.un.org/ru/letsfightracism/pdfs/united_against_racism.pdf (accessed on 20 December 2020). 
This article will touch upon two types of discrimination against Christians, the most common in the Global North, and which are increasingly resonating in the Global South, including as a result of significant pressure in the human rights sphere, as well as the direct prosecution and persecution of Christians for professing their own faith in the Global South. With regard to the discrimination against Christians, the article will study examples of prosecution (disciplinary, administrative, and criminal) for refusing to perform an abortion on grounds of conscience and religion and for refusing to provide services to LGBT people when this conflicts with the Christian conscience of the provider. The prosecution and persecution of Christians for their faith in the countries of the Global South will be considered in the context of the international obligations assumed by states to respect the right to freedom of thought, conscience, and religion.

\section{Refusing Abortion Is a Right and Duty of a Christian}

This section provides a comparison of the rights of various subjects who find themselves connected through abortion (a woman, an unborn child, and a medical worker). The scope and protection of these rights are exemplified by the International Bill of Human Rights $^{5}$ at the universal level and the practice of the ECHR at the regional level as international legal basis for comparison and several cases from the practice of the states of the Global South.

The authors reveal the disproportion of the attention to "abortion rights" in comparison with the right to freedom of religion in the interpretation of human rights treaties. The authors also stress that the disbalancing of human rights is, firstly, in place and leads to the violation of religious rights entitled to protection, even in cases where the balance could easily be found, and, secondly, disbalancing is carried out by gross distortions when the obligations of the states are being presented as obligations of individuals or when the proportionality of measures affecting the religious rights is one-sidedly assessed (only right against right and not, additionally, severity of limiting measures against other measures available). Here, the issue is not even about the uniformity of Christian denominations in abortion questions (although the "pro-choice" position is marginal among the Christian denominations; cf. (Schlesinger 2017) but about the right to be protected by international law on the part of those who, from a religious point of view, consider abortion to be a murder, as literally proven by the Ecclesiastical position of, e.g., Orthodox and Catholics, as cited below.

An abortion in medicine means "termination of pregnancy in the first 28 weeks, when the fetus is not yet viable". ${ }^{6}$ In this way, the development of medicine makes it possible to save the life of an infant at an ever earlier stage and with the decreasing weight of the child at birth. In connection with the physiology of a pregnant woman, abortions are of two types: spontaneous and artificial. This article discusses exclusively the latter.

Starting from the second half of the twentieth century, abortion legislation has been steadily liberalized, often while retaining the provisions of relevant national regulations that allow medical practitioners to refuse to perform abortion for the reasons of conscience (Chavkin et al. 2017, p. 55).

The fact of artificial termination of pregnancy raises human rights issues in relation to three subjects (a woman carrying a child, an unborn child, and a medical practitioner who performs an abortion or refuses to perform it). Accordingly, in the International Bill of Human Rights and General Comments issued by the United Nations Human Rights Committee and the United Nations Committee on Economic, Social and Cultural Rights, we can find in the context of abortion the rights of women (right to life, right to the highest attainable standard of health, principle of non-discrimination and others), the rights of the child (but not the unborn), and the rights of the medical practitioner (the right to freedom of thought, conscience, and religion).

5 The "International Bill of Human Rights" is a collective name for the Universal Declaration of Human Rights (1948), the International Covenant on Economic, Social and Cultural Rights (1966), and the International Covenant on Civil and Political Rights (1966) and its two Optional Protocols.

6 Great medical encyclopedia of Petrovsky B.V. Available online: https: / бмэ.орг / (accessed on 20 December 2020). 
The right to life is enshrined in Art. 3 of the 1948 Universal Declaration of Human Rights and Art. 6 of the International Covenant on Civil and Political Rights of 1966. The International Covenant on Civil and Political Rights 1966 in paragraph 1 of Art. 6 contains provisions prohibiting arbitrary deprivation of life. Derogation from the right to life is not permitted in any situation (UN HRC 2018, para. 1).

The voluminous paragraph 8 of the Human Rights Committee's General Comment No. 36 (2018) is devoted entirely to abortion in the context of the right to life (UN HRC 2018). Paragraph 8 contains a range of restrictions on the states party to the covenant in limiting the voluntary termination of pregnancy; it includes a series of "positive obligations" of states to guarantee "safe, legal and effective access to abortion" and advocates against unsafe abortions, where "unsafe" is used as a synonym for "illegal", as if abortion per se is a harmless manipulation.

Paragraph 8 states that

"restrictions on the ability of women or girls to seek abortion must not, inter alia, jeopardize their lives, subject them to physical or mental pain or suffering that violates article 7 of the Covenant, discriminate against them or arbitrarily interfere with their privacy" ${ }^{\prime \prime}$.

It specifically recommends, inter alia, the removal of barriers that deny effective access by women to safe and legal abortion, "including barriers caused as a result of the exercise of conscientious objection by individual medical providers" (emphasis added by the authors).

In 2016, the Committee on Economic, Social and Cultural Rights adopted General Comment No. 22 on the right to sexual and reproductive health (Article 12 of the 1966 International Covenant on Economic, Social and Cultural Rights) (UN CESCR 2016). According to the provisions of this document, it is important to consider the availability of qualified medical personnel, medicines, including medicines for abortion and for post-abortion care (para. 13); access to and dissemination of information on sexual and reproductive health issues (para. 18); access, on an equal basis with men, to medical services, medicines, and legal methods of termination of pregnancy, and contraceptives (para. 28); elimination or restriction of state's adoption of such laws, the action and implementation of which causes the restriction of the ability of individuals or groups of individuals to have the last rights to sexual or reproductive health, including the prohibition of abortion or criminal liability for them (para. 34); compliance with medical data (p. 40); cancellation of such a right in the future, restricting the rights of individuals to sexual and reproductive health, interference with such rights by third parties (para. 41), and others.

In 2000, the Human Rights Committee issued its General Comment No. 28 on Article 3 of the International Covenant on Civil and Political Rights of 1966, where the abortions appeared as indicators (para. 5) and consequences (paras. 10,11) of inequality between men and women and where certain regulatory measures on abortions were named among examples of discriminatory violations of women's rights (para. 20) (UN HRC 2000).

The considered human rights documents pass over in silence the unborn child, the reason for which can be considered the lack of consensus between states regarding the legal basis of the very beginnings of human life. The Universal Declaration of Human Rights implicitly links legal personality to birth, since its Article 1 begins with the following words: "All human beings are born free and equal in dignity and rights (emphasis added)". However, the American Convention on Human Rights of 22 November 1969, in Art. 4.1, states the following: "Every person has the right to have his life respected. This right shall be protected by law and, in general, from the moment of conception".

In solidarity with the Christian view of the origin of human life from the moment of conception, see (Ling 2017; Disney and Poston 2010), and taking into account the attention that is paid to arbitrary deprivation of life (UN HRC 2018, para. 6, para. 7, Section II "Prohibition against arbitrary deprivation of life"), the eradication of the death penalty

7 Mentioning women and girls separately is based on the age gradation of adults (over 18 years old) and children (up to 18 years old, inclusive). 
(UN HRC 2018, paras. 32-51) in the context of the right to life, we cannot call the provisions of para. 60 of General Comment No. 36 (2018) anything other than a mockery:

"When taking special measures of protection, States parties should be guided by the best interests of the child, and by the need to ensure survival, development and well-being of all children /emphasis added, footnotes omitted/". (UN HRC 2018)

From a human rights perspective, a physician who refuses to perform an abortion for reasons of conscience must be protected by the right to freedom of conscience, religion, or belief.

As of 16 October 2020, the interpretation of Article 18 of the International Covenant on Civil and Political Rights of 1966 was given for the last time as long ago as in 1993 (UN HRC 1993). General Comment No. 22 (48), recognizing the right to freedom of thought, conscience, and religion (including freedom of belief) as "far-reaching and profound" (para. 1), is only four typewritten pages long, has 11 paragraphs $^{8}$, and is rather general (UN HRC 1993). Of the actions that may be due to religious beliefs, the document mentions only refusal to perform military service (para. 11). It also states, "no manifestation of religion or belief may amount to ... advocacy of ... hatred that constitutes incitement to discrimination, hostility or violence" (para. 7). The latter provision, in light of the aforementioned links of inequality between men and women with the problem of abortion in General Comment No. 28 (2000) (UN HRC 2000), in fact, is directed against the right of a medical practitioner to refuse abortion on grounds of conscience.

General Comment No. 24 (2017) of the Committee on Economic, Social and Cultural Rights, dedicated to the obligations of States under the International Covenant on Economic, Social and Cultural Rights in the context of business, also mentions the right of a physician to refuse an abortion on grounds of conscience when analyzing "the increased role and impact of private actors in traditionally public sectors, such as the health or education sector ... " (para. 21) (UN CESCR 2017). The Committee recommends to the states that "Private providers should be subject to strict regulations that impose on them so-called "public service obligations". For instance, where health practitioners are allowed to invoke conscientious objection to refuse to provide certain sexual and reproductive health services, including abortion, they should refer the women or girls seeking such services to another practitioner within reasonable geographical reach who is willing to provide such services" (para. 21).

Three significant problems are present in the two quotes above. Firstly, again, it is about ensuring the rights of pregnant women and girls, and not the doctors, while the entitlement to protection of the latter should have been mentioned or even stressed, too. Secondly, the obligation is shifted to the doctor and does not remain with the state or, in this case, with the business entity-for example, in the form of the obligation to ensure the availability of abortion, despite the presence of religious health workers and without infringing on the right to freedom of belief of the latter. Thirdly, the document refers to General Comment No. 22 (2016) on the right to sexual and reproductive health, but not to General Comment No. 18 (1993) on the right to freedom of thought, conscience, and religion. This omission could have been easily avoided with the use of a more balanced text.

The European Court of Human Rights (hereinafter referred to as the ECHR or Court) has considered a number of cases related to abortion: cases concerning the abortion procedure and the violation of women's rights to perform it (ECHR 1980; ECHR 2010; ECHR 2004, etc., as well as Council of Europe: European Court of Human Rights 2016; see also Puppinck 2013), as well as concerning the right to religion and non-abortion (ECHR 2007; ECHR 2011; ECHR 1989, etc.). It can be said that the position of the Court is generally pro-abortion. It seems that the reason for this state of affairs is the de-Christianization of Western European society, expressed, among other things, in the development of the concept of so-called somatic human rights. 
Paragraph 3, clause XII.2 of the 2008 Fundamentals of the Social Concept of the Russian Orthodox Church states that "faithfulness to the biblical and patristic teaching on the holiness and invaluableness of human life from its very origins is incompatible with the recognition of a woman's "freedom of choice" to dispose of the fate of the fetus" (Fundamentals of the Social Concept of the Russian Orthodox Church 2008). However, it is precisely this "freedom of choice" that is the human rights consequence of the development of the concept of so-called somatic human rights, which are increasingly asserted at the universal and regional levels of human rights protection by international legal means.

In 2020, the European Court of Human Rights rendered judgments in the cases of two nurses from Sweden (Ellinor Grimmark and Linda Steen) who trained as midwives and were refused employment in Sweden due to their conscientious objection to abortion (ECHR 2020a, 2020b). After the judgments were made against Ellinor Grimmark and Linda Steen by the Swedish courts, the nurses appealed to the European Court of Human Rights, but the latter refused to consider these cases as manifestly unfounded.

The grounds for the appeal to the ECHR are similar for the two applicants. Each of them completed midwifery training funded by a Swedish government program and received a license to practice midwifery in Sweden but were subsequently denied midwifery work when they declared their Christian faith and refusal to participate in abortion. The nurses referred to norms of discrimination and violation of their freedom of conscience.

In both decisions, the Court found that it was a Christian belief that prevented the applicants from participating in abortion and that per se this civil stance is entitled to protection (para. 25 Grimmark case, para. 20 Steen case). Or, in other words, conscientious objection to abortion constitutes the exercise of religion within the meaning of Art. 9 of the Convention, and therefore, in both cases, there was an interference with freedom of religion (para. 25 of the Grimmark judgment, para. 20 of the Steen judgment). However, such interference is subject to the provisions on limiting the exercise of religion, "which are prescribed by law and are necessary in a democratic society in the interests of public safety, for the protection of public order, health or morals, or for the protection of the rights and freedoms of others", as enshrined in Art. 9 (2) of the Convention.

The Court unreasonably noted that the domestic courts carefully balanced the different rights against each other and provided detailed conclusions that were based on sufficient and relevant reasoning. A proper balance was thus allegedly struck between the different, competing interests (para. 27).

It seems that here, just like in the judgment on the Eweida case, which will be discussed in the next section of the article, the Court again confuses whose rights it is intended to balance. Obviously, the balance as sought by the Court here is between the "women's right to abortion", Sweden's "positive obligation" to organize the healthcare system for this "right", the employer's right to demand from all employees the entire scope of work, but not the right to freedom of religion of the health worker. In no way can a conclusion be made from the brief findings of the Court that the religious convictions of believers were recognized as eligible to be taken into account and be adapted to by the state, as is done with the healthcare system where the state adapts to the interest of a woman to get rid of a child she is carrying.

Under Art. 14 of the Convention (on discrimination), the Court also refused to consider the case as manifestly unfounded. The European Court of Human Rights agreed with the conclusion of the Swedish Discrimination Ombudsman, that the religious faith as such was at stake because "another midwife refusing a part of the work other than on religious grounds would not have been treated any differently from the applicant" (para. 10). Here, one can only regret that the applicant did not formulate the comparison groups as "midwives with convictions of conscience that do not allow abortion" and "midwives without convictions of conscience that do not allow abortions".

It is noteworthy that the Court links the proportionality of the restriction of the right to religion only with the protection of another right, but not with the fact that the restriction itself must be proportionate to other means available to the state to achieve a legitimate 
goal (to provide certain services, in this case)—for example, availability of personnel who agree to perform abortions; see (Domenici 2020).

Surprisingly, the ECHR "does not see" that its decisions, reducing the entire work of a midwife to abortion, and not, in fact, to obstetric aid, deprive Christian believers of the opportunity to participate in the accompaniment of labor. In other words, in this judgment, the Court did not even try to strike a balance between the woman's right to abortion, enshrined in Swedish law, which is derived in the Court's practice from the right to privacy under Art. 8 of the Convention, and the right to freedom of religion directly guaranteed by the 1950 European Convention on Human Rights. On the contrary, the Court established a rigid hierarchy of rights that is not envisaged in the Convention. Roughly, the right to freedom of religion is the last human right to be protected; precedence should be given to any other human right. The Court limited the employment opportunities of Christian believers in a certain area of medical activity (obstetrics) in a discriminatory manner on the basis of religion. Notably, the employment in obstetrics generally lies outside the scope of the Convention and, in the considered case, cannot be related to the protection of the right to life of a woman due to the general nature of the prohibition actually imposed by the Court and the classification of abortion in general as the right to respect for private and family life.

As a matter of fact, the Court shifted the responsibility for the state's implementation of its obligations to provide abortion services to the applicants, as if depriving Christian believers of obstetric activity because of their refusal to perform abortions was the only means available to the state to achieve access to abortion throughout the country.

Three cases from the law enforcement practice of the Global South states indicate the spread of similar approaches in this region.

In 2009, in Brazil, the Catholic Church excommunicated the mother of a nine-year-old girl who was raped by her stepfather, who gave her consent to an abortion, and doctors who performed the abortion. ${ }^{9}$ This decision was approved by the head of the Vatican Congregation for Bishops, Cardinal Giovanni Battista Re, but was strongly condemned by a part of society, including the President of the country, who spoke out "as a Christian and a Catholic", although the measures taken are ecclesiastical, not secular-the stepfather accused of rape was arrested to investigate the case.

In 2014, press covered the case of Bogdan Chazan, a Polish physician who, on Christian grounds, refused to perform an abortion on a woman whose child was unlikely to survive, according to doctors. The doctor did not inform the woman that after 24 weeks of pregnancy, she would not be able to have an abortion legally (according to Polish law, abortion procedures are allowed before the 25th week of pregnancy, "unless the life of the expectant mother or her child is in danger, as well as cases of incest or rape"). ${ }^{10}$ During the court proceedings, it was established that the doctor "had the right to refuse the procedure because it contradicted his Catholic faith, but was legally obliged to refer the patient to another doctor for an abortion procedure" ${ }^{11}$ The Catholic Church condemned the actions of the authorities regarding the dismissal of Bogdan Chazan from the post of director of the city's Holy Family hospital in Warsaw, but the decision remained in force.

The third case is the one of a doctor from Argentina who refused to abort the fetus of a woman in her 23 rd week of pregnancy. ${ }^{12}$ In this case, a pregnant woman who was raped by a member of her family came to the Fernandez Oro hospital, where her condition was assessed by doctors. As a result, the woman was referred to the Pedro Mogillaski hospital in Cipoletti to terminate the pregnancy. The facts of the case further indicate that, at the

9 The Vatican supported the excommunication of a Brazilian woman who allowed her 9-year-old daughter to have an abortion. Available online: https: / / www.newsru.com/religy/10mar2009/abort.html (accessed on 20 December 2020).

10 Polish doctor dismissed in "abortion refusal" case, 9 July 2014. Available online: https:/ / www.bbc.com/news/world-europe-28225793 (accessed on 20 December 2020).

11 Ibid.

12 Argentinian doctor found guilty for refusing to abort 23-week-old baby. 22 May 2019. Available online: https://www.lifesitenews.com/news/ argentinian-doctor-found-guilty-for-refusing-to-abort-23-week-old-baby (accessed on 20 December 2020). 
Cipoletti hospital, Dr. Rodriguez did not become fully persuaded that the woman had been given oxaprost (misoprostol) to induce an abortion, as generally this medication is given at yearly stages of pregnancy, but came to the conclusion of a risk of a serious and even life-threatening infection and prescribed relevant treatment. According to the testimony of the accused Dr. Rodriguez, the woman in the hospital was told that the intention of the doctors was to keep her until the possibility of a caesarean section, to which she gave her consent. As a result, a healthy child was born at 7.5 months of pregnancy, who, at the time of the hearing, was two years old.

The case was opened by the state prosecution and was legally related to the violation of the abortion law by inaction by Dr. Leonardo Rodriguez Lastra, whose refusal to perform an abortion late in pregnancy (23 weeks) was qualified by the court as "obstetrical violence", for which a penalty was imposed in the form of a suspended sentence of two years, subject to its replacement with a real imprisonment in the event of a repetition of a similar incident. The doctor was also under threat of being removed from the register of licensed doctors. According to the state prosecution, Dr. Rodriguez could not be convicted of violating the principle of conscience, since he "did everything possible not to perform the abortion procedure". They therefore demanded that he be convicted for "obstruction of the legal abortion procedure", since the woman who Rodriguez refused to perform an abortion on was raped by a family member in Fernandez Oro, and according to the Supreme Court, a woman reporting a rape does not have to prove that her pregnancy is the result of sexual assault, and she does not have to disclose the identity of the aggressor. In this case, Dr. Rodriguez Lastra did not question his patient's sincerity. Dr. Rodriguez Lastra, in his defense, referred to "the laws of his conscience" that prevented him from inflicting death on a child, as well as the dire consequences of late abortions.

The lawsuit has attracted a lot of media attention in Argentina, as abortion is illegal in the country but not punishable in so-called "extreme cases", which include pregnancy as a result of rape. ${ }^{13}$ It is noteworthy that the trial itself was initiated by the deputy of the Rio Negro, Marta Milesi, who advocates for abortion and the introduction of relevant provisions into legislation. It was established during the questioning of the victim that she did not support the charges against Dr. Rodriguez.

Despite public support and approval for the actions of the accused Dr. Rodriguez, an indictment was brought against him.

Summing up, it is important to note that the Orthodox Church adheres to the position of the beginning of human life from the moment of conception, as reflected, for example, in the 2008 Fundamentals of the Social Concept of the Russian Orthodox Church:

"Since ancient times, the Church has considered the intentional termination of pregnancy (abortion) as a grave sin. Canonical rules equate abortion with murder. This assessment is based on the conviction that the birth of a human being is a gift from God, therefore, from the moment of conception, any attempt on the life of a future human person is criminal". (para. 1, clause XII.2)

Regarding the doctor's actions, the Concept says:

"Sin falls on the soul of the abortion doctor. The Church calls on the state to recognize the right of medical workers to refuse abortion for reasons of conscience. It cannot be recognized as normal when the legal responsibility of a doctor for the death of the mother is incomparably higher than the responsibility for the destruction of the fetus, which provokes health workers, and through them patients, to perform an abortion /emphasis added/. The physician should exercise maximum responsibility for making a diagnosis that can push a woman to terminate her pregnancy; at the same time, a believing physician must carefully compare medical indications and the dictates of the Christian conscience". 
The Catholic Church, in stating a similar position, adds another important emphasis: "It is completely unacceptable ... to resort to abortion, even if it is done for the purpose of healing" (Humanae Vitae 1968).

Unfortunately, current trends in the interpretation of states' human rights obligations go in exactly the opposite direction: the murder of an unborn child is not simply recognized as murder but is regarded as a welcome element of "a woman's decent life without pain and suffering", while the Church makes no exception in its qualification of abortion as a sin, even for cases of conceiving children as a result of heinous crimes against women or girls.

States are encouraged by a plurality and variety of ways to prioritize a woman's right to life on earth, a woman's freedom of "reproductive choice" and her equality with a man over a doctor's right to freedom of opinion with implications for eternal life.

From the point of balancing different rights, the authors wish to stress that their position is not in proclaiming that it is only the freedom of religion that is entitled to protection. On the contrary, the authors attempted to demonstrate that the right to religion is entitled to protection, too, even in a time when abortion is considered by some to be a norm. The unjustified lack of balance is proven to be at the expense of the freedom of religion only. Point by point, the remedies were offered above, namely, in one case, the balance could be gained by a reference to one more document; in another case by the correct distributing of obligations between the state, the employer, and the employee; in the last case by the correct proportionality test of measures that limit human rights.

The situation is similar with the prioritization of the so-called "rights" of the LGBT persons in relation to the rights of the faithful Christians.

\section{Christians' Right to Freedom of Religion vs. LGBT "Rights"}

First of all, it is important to note with regard to the "rights" of LGBT persons that LGBT persons do not have special rights that belong only to them. LGBT persons have all the same rights that non-LGBT individuals have, including the right to non-discrimination based on their relationship to any social group.

As the Vice Chairman of the UN Committee on Economic, Social and Cultural Rights, Professor Aslan H. Abashidze, points out, we are talking about an attempt to construct particular cases of individuals associated with their so-called "orientation" to the rank of a global problem and also about giving them a legitimate character in the absence of any international legal framework. The requirement to legislate additional signs of nondiscrimination on the basis of "sexual orientation" and "gender identity" and to allow the registration of same-sex marriages, adoption/adoption of children by same-sex couples, etc., is unfounded from an international point of view. Professor Abashidze gives an example of a conversation with the nature of a paradox: "The ambassador of one of the African countries in Geneva witnessed a conversation between a diplomat from the UK and a diplomat from the countries of the former British colony. A diplomat from Great Britain rebuked a diplomat from a country-a former colony for the fact that same-sex marriage is criminalized in his country. In response to this reproach, the diplomat began to justify the position of his country, referring to the common law of Great Britain, according to which same-sex marriage is considered a crime against the human race (against nature of human), in other words, a more serious act than a criminal offense. And then the diplomat concluded: if Great Britain abandoned its own precedent, then his country is not obliged to do this, because it is no longer a British colony" (Abashidze and Klishas 2015, pp. 138-39).

However, at the international level, there is a lobby that is trying to create some special rights for LGBT persons, leading to a conflict with the international obligations of states to provide equal protection to all people, regardless of their sexual orientation, without any discrimination. The creation of special "rights" leads to a violation of the religious rights of Christians, including the right to live in accordance with their beliefs and not to participate in what is contrary to their religious beliefs-for example, in the registration of same-sex unions that are considered to be a grave sin. The Scripture defines sodomy as a mortal sin 
(1 Epistle to the Corinthians 6:9; Epistle to the Romans 1:26-27, 32). St. John Chrysostom in the 4th Homily on the Epistle of Apostle Paul to the Romans calls this sin the most serious of all sins (St. John Chrysostom n.d.). This doctrine is professed by the majority of Christian denominations (Orthodox, Catholics, most Protestant churches, including Seventh-Day Adventists, most Baptist, Methodist, and Pentecostal churches), the total number of which is more than 2 billion; see (Melton and Baumann 2010).

From a formal point of view, it is quite difficult to prove direct discrimination when a person is fired from work for Christian beliefs. Indirect discrimination is much more common when, for example, an employer implements a generally applicable policy, scheme, or practice that has a seemingly legitimate business purpose. Examples of indirect discrimination might include an internal requirement that all employees attend horse races with clients or a rule that requires all employees to wear badges or other similar items to support a cause that is contrary to Christian beliefs. ${ }^{14}$

At the same time, it should be recognized that the line between direct and indirect discrimination is not always clearly visible. Especially under the guise of "good goals", states remove cases of direct and indirect discrimination from the category of violations of the right to freedom of conscience. In this sense, the decision of the European Court of Human Rights (ECHR) in the case of Eweida and others v. Great Britain is illustrative (ECHR 2013). This case brings together four cases of discrimination against Christians for professing their faith (Ms Nadia Eweida, Ms Shirley Chaplin, Ms Lillian Ladele, and Mr Gary McFarlane). All cases relate to dismissal from work for professing the Christian faith, but in the context of this section of the article, it is important to consider two of them (Ms Lillian Ladele and Mr Gary McFarlane), which related to the "rights" of LGBT people.

In the case involving Lillian Ladele, the registrar of births, marriages, and deaths, she refused to register same-sex civil partnerships because it was contrary to her Christian beliefs. The ECHR found that the employer's requirement that all registrars be involved in registering same-sex civil partnerships had a harmful effect on L. Ladele, conflicting with her religious beliefs. However, the ECHR did not find a violation of Art. 9 of the ECHR in this case, since it considered that the policy of the local registration authority is aimed at ensuring the rights of others, who are also protected by the ECHR; therefore, the national authorities did not go beyond their discretion.

In this case, the position of the ECHR and the national authorities can hardly be considered adequate. L. Ladele never expressed any disrespectful attitude towards samesex couples. Of course, these couples did not know that she was informally negotiating with her colleagues to replace her in order not to participate in such registrations. In other similar local registration authorities, workers were allowed not to participate in registering same-sex civil partnerships due to their religious beliefs. Therefore, one can hardly talk about any discrimination against same-sex couples. Two judges of the ECHR, Vucinic and De Gaetano, who participated in this case, took this position (there was not any discrimination against same-sex couples).

In addition, it is important to note that when L. Ladele signed an employment contract when she was hired, there was no obligation to participate in registering same-sex civil partnerships. These requirements were introduced later. As a result, L. Ladele preferred to lose her job than to compromise with her conscience (Semenova and Kiseleva 2017, p. 59-66).

It appears that, in this case, there is no legitimate aim for interference with the law, and such interference cannot be considered "necessary in a democratic society". It should also be added that there is the state religion established in Great Britain-Anglicanism. In light of this fact, the refusal to protect the Christian beliefs of a citizen of the United Kingdom for the sake of sexual perversion that is contrary to the culture-forming religion looks at least strange.

14 For more information on direct and indirect discrimination, see, for example, An Employer's Guide to Christian Beliefs. Christianity in the Workplace. Vienna, 2018, p. 12. Available online: https://adfinternational.org/resource/christianity-in-the-workplace-an-employers-guide-tochristian-beliefs / (accessed on 20 December 2020). 
In the case of G. McFarlane, the applicant worked as a consultant for a confidential sex therapy and relationship service. He was fired for refusing to counsel homosexual couples because he considered it incompatible with his religious beliefs. The ECHR found that his refusal to provide counseling for homosexual couples amounted to a practice of his religion and belief. However, the Court considered that the "policy of providing services without discrimination" was a legitimate purpose for interference with the law; therefore, the Court did not establish violations of Art. 9 of the ECHR.

These precedents give rise to well-grounded concerns, since the practice is being formed of refusing Christians to live and act in accordance with their religious beliefs, especially, in a culturally Christian country.

On the one hand, the member states of the Council of Europe are trying to provide additional guarantees to religious minorities, saying that this is an important step towards preventing religious persecution in the future. Thus, according to the Preamble of the 1995 Council of Europe Framework Convention for the Protection of National Minorities, the member states of the Council of Europe and other states signatory to this Framework Convention believe that "a pluralist and genuinely democratic society should not only respect the ethnic, cultural, linguistic and religious identity of each person belonging to a national minority, but also create appropriate conditions enabling them to express, preserve and develop this identity". ${ }^{15}$ According to the position of the Council of Europe, "cultural diversity should be seen as a matter of enrichment rather than division" (Murdoch 2012, p. 15). "A Europe of much diversity and many faiths calls for special concern for the protection of the exercise of the freedom of thought, conscience and religion" (Murdoch 2012, p. 16).

On the other hand, the ECHR takes the directly opposite position, refusing to practice their religion not to a religious minority but to a religious majority, in order to defend the so-called "rights" of persons with non-traditional sexual orientation and in those cases where there is in fact no discrimination against these persons.

It is quite obvious that "in the same way that a national or ethnic identity cannot be 'switched off' at work, an individual should not be expected to leave their faith at home". ${ }^{16}$

However, it should be noted that there are positive trends in countries such as Poland. For instance, on 26 June 2019, the Polish Constitutional Court confirmed that service providers and business owners have the right to conduct their business in accordance with their religious beliefs, without being subject to criminal prosecution. The decision of the Constitutional Court overturned a previous decision of the Supreme Court of Poland, which upheld a criminal charge against the owner of a printing house in Lod Await, who refused to print documents advertising an event contrary to his conscience and was found guilty on the grounds that his religious beliefs were not a "just cause" for refusing to provide their services. The Constitutional Court noted that the words "without a valid reason" cannot be clearly defined; therefore, "punishment for refusing to provide services without a valid reason" in accordance with Art. 138 of the Polish Criminal Code constitutes a violation of the service provider's freedoms, particularly the freedom of contract, the right to express one's opinion or to act in accordance with one's conscience. The reporting judge added that the fight against discrimination cannot be fought at the expense of these freedoms. As a result, the Constitutional Court declared Article 138 of the Polish Criminal Code unconstitutional. ${ }^{17}$

This positive example is rather an exception to the rule, since, as noted by Robert Clarke, director of the European law firm ADF International, recently, the right to freedom of conscience

15 Council of Europe Framework Convention for the Protection of National Minorities. Strasbourg, 2013. Available online: https:/ /www.coe.int/en/ web/minorities/text-of-the-convention (accessed on 20 December 2020).

16 An Employer's Guide to Christian Beliefs. Christianity in the Workplace. Vienna, 2018, p. 10. Available online: https://adfinternational.org/ resource/christianity-in-the-workplace-an-employers-guide-to-christian-beliefs/ (accessed on 20 December 2020).

17 For more details, see Le Tribunal constitutionnel polonais se prononce en faveur de la liberté de conscience. Available online: https: / adfinternational. $\mathrm{org} /$ news/polish-constitutional-tribunal-rules-in-favour-of-freedom-of-conscience-fr/ (accessed on 20 December 2020 ). 
"has regularly been challenged in various countries in Europe. Across Europe, citizens are facing an impossible choice: either violate their conscience or face punishment by the state. This ranges from medical professionals to bakeries, who are forced to choose between their convictions and their profession. They risk criminal charges, fines, loss of reputation, and social discrimination. Nobody should face this simply for living in accordance with what they believe" ${ }^{\prime 18}$

Strange as it may seem, the reason for this state of affairs is the policy of tolerance. How this policy manifests itself can be traced in some quotes from the round table "Religion and Religious Freedoms in International Diplomacy", which was organized on 22 September 2016 by the UN Special Rapporteur on Freedom of Religion or Belief in cooperation with the World Council of Churches. Some examples are as follows: "Tolerance is not about ignoring other religions"; "One religion nourishes another. I am because you are"; "Without the Buddha, I may not be a Christian", etc. ${ }^{19}$ It seems that these quotes do not require additional comments due to their obvious absurdity. However, for a correct understanding of the "policy of tolerance", it is important to briefly define the concept of the term "tolerance".

Regarding the concept of tolerance, it should be noted that in some languages, e.g., in Russian, there are two different terms translated into English by the same term "tolerance" (cf. in Russian "терпимость"—-terpimost and "толерантность"-tolerantnost).

The first term "tolerance" ("terpimost") has Christian roots and is reduced to the commandment "Judge not, that ye be not judged" (Matthew 7:1). This commandment means that we have no right to condemn specific people for their sins. However, as Christians, we are obliged to condemn the very behavior or deeds as a sin, if the Holy Scripture testifies to it.

The second term, "tolerance" ("tolerantnost"), is derived from the medical term "tolerance", which was introduced in 1952 by the English biologist Peter Brian Medawar (who received the Nobel Prize "for discovery of acquired immunological tolerance"), namely the immunological state of the organism, in which he is not able to synthesize antibodies in response to the introduction of a specific antigen while maintaining immune reactivity to other antigens, cf. (Billingham et al. 1953). Complete tolerance is death.

After this term found its way into the humanities, it became interpreted in different ways. In Russian, two different terms easily show the difference, but in English, there is a confusion of concepts.

For the purposes of this study, it is important to point to the second term "tolerance", which means a calm, indifferent, incurious attitude towards any behavior of people, which does not directly affect their own rights and does not violate the current legislation (Semenova 2014, pp. 39-40). In other words, we can say that tolerance means not reacting to evil. Negative reaction to sin has been laid down in every human being since creation. However, with the departure from Christianity and, consequently, from the moral assessment of acts contrary to the Law of God (Semenova 2019, pp. 28-36), the mechanism of reaction to evil gradually atrophies, and a significant part of the Western European community does not see any problem in unnatural vices that are enshrined at the legislative level as a norm of behavior. Nevertheless, Christians who follow the moral law retain a negative reaction to sin, so they try to call on their fellow men to protect and preserve the traditional values of humankind, which have been the basis of European civilization. However, the response to this call is exactly the opposite.

Thus, at the universal level, in March 2016, the UN Committee on Economic, Social and Cultural Rights adopted General Comment No. 22 "On the Right to Sexual and Reproductive Health" (Article 12 of the ICESCR), which was already mentioned in the previous section of this article. Comment 22 not only promotes abortion but also nontraditional relationships at the level of all UN members. The Committee requires states to

18 Ibid.

19 Religion and Religious Freedom in International Diplomacy. Workshop Summary Brief. 22 September 2016. Available online: https://www.ohchr. org/Documents/Issues / Religion/WorkshopReligion.pdf (accessed on 20 December 2020). 
ensure full respect for the representatives of the so-called "sexual minorities" in relation to their "sexual orientation, gender identity and intersex status" (paragraphs: 23, 30, 59, etc.).

It should be noted that General Comments are not binding but serve as a guideline in the fulfillment by states of their obligations under the covenant, since they usually express the agreed position of states in the understanding and interpretation of a specific enshrined right. With regard to Comment 22, it can be confidently asserted that the indicated position to consolidate the so-called "LGBT rights" cannot be considered universally recognized and agreed. In particular, the position of the Russian Federation and a number of countries of the Global South in solidarity with it expresses a harshly negative attitude towards such an interpretation, considering it absolutely unacceptable.

Unfortunately, the above examples confirm the general trend in the countries of the Global North with Christian roots, which the states of the Global South are gradually beginning to follow. As His Holiness Patriarch Kirill of Moscow and All Russia noted, secularism is the reason for the loss of Christian identity in Europe:

[S] upporters of the secular idea believe that rejection of religion serves the common good of all people. Along with religiosity, traditional moral values such as marriage, the union of a man and a woman, and the inviolability of human life from the moment of conception to natural death are rejected. Those who find the strength and courage to publicly criticize unnatural and moral permissiveness are accused of intolerance by representatives of the secular idea. We take to heart the situation in Europe, which was once a stronghold of Christianity, and is now rapidly losing its religious identity. ${ }^{20}$

It should be noted that the policy of tolerance and the loss of Christian values in the countries of the Global North is a more terrible persecution against Christians than all the combined prosecution and persecution of Christians in some parts of the Global South. As St. John Chrysostom wrote, the most terrible of persecutions is the absence of persecution. "While people are saying, "Peace and safety," destruction will come on them ... " (1 Thess. $5,3)$. However, prosecution and persecution of Christians in the 21st century for professing their faith is an international crime.

\section{Prosecution and Persecution of Christians in the Global South}

At the end of December 2017, a meeting dedicated to the safety of Christians in the Middle East and beyond was held in Vienna on the sidelines of the OSCE Council of Foreign Ministers, initiated by Russia and Hungary. The meeting was attended by representatives of OSCE member states, Orthodox and Catholic churches, as well as religious and public figures, diplomats, and journalists. During the meeting, it was noted, in particular that in the Middle East and North Africa, believers and clerics come under attack by terrorist groups and are forced to leave places their communities have lived in for centuries; instances of desecration or destruction of Christian shrines are not uncommon and go unpunished; in Ukraine, desecration and seizure of temples by extremists and violence against clergymen and believers are supplemented by the attempts of official authorities to impose restrictions on the activities of the canonical Ukrainian Orthodox Church. $^{21}$

Today, the African continent unites 55 states with a population of over 1.3 billion people. According to available statistics, $46 \%$ of the African population is Christian, i.e., approximately 600 million people. ${ }^{22}$

20 Patriarch Kirill named the reason for the loss of Christian identity in Europe. Available online: https:/ /ria.ru/20191114/1560925226.html?in=t (accessed on 20 December 2020).

21 Message for the media. OSCE, “On a joint Russian-Hungarian meeting at the OSCE on the safety of Christians in the Middle East and beyond", Available online: http://www.mid.ru/foreign_policy/news/-/asset_publisher/cKNonkJE02Bw/content/id/2981209 (accessed on 20 December 2020).

22 In Africa, the number of Christians has exceeded the number of Muslims, Site of the Church Scientific Center "Orthodox Encyclopedia". Available online: https: / / www.sedmitza.ru/text/3200526.html (accessed on 20 December 2020). 
Christian sacred history and sacred tradition are inseparable from the ancient and early medieval history of the countries of North and North-East Africa. In the Old Testament and the New Testament, we repeatedly find references to Africa. The Coptic Church in Egypt deserves special attention. In the Eastern Desert and Upper Egypt, famous monasteries were built and masterpieces of original Coptic architecture, icon painting, and literature were created. In Alexandria and Cyrenaica, Christian literary works were written in Greek (Vasiliev 2010, p. 882). Yet today, various media give us horrifying examples in Africa of cases of the murder of Christians, violence against Christian women, forced conversion of Christians to Islam, accusations of insulting Islam, often punishable by death, destruction of churches, persecution of Christians from historical lands. The escalation of violence against Christians has recently become systemic. The mass exodus of Christians from Africa could upset the centuries-old religious balance.

One of the obstacles for this issue to be properly addressed at the international level is the lack of a legitimate mechanism for collecting information. One can rely on data from various non-governmental organizations (NGOs). ${ }^{23}$ For example, the NGO "Gatestone Institute" calls what is happening in Nigeria "the genocide of Christians" - in June 2018 alone, 238 people were killed. ${ }^{24}$

In 2014, France published the "Black Book on the condition of Christians in the world", with the contributions of 70 French and foreign experts, historians, journalists, priests, and human rights activists. According to the authors' estimates, 150-200 million Christians in 140 countries of the world have become victims of discrimination, and the Christian religion has become the most persecuted in the world. ${ }^{25}$

To be objective, we shall note that there are certain positive aspects of special protection of the rights of Christians. For example, in 2016, the Egyptian Parliament passed a law to facilitate the construction of new Christian churches in the country. ${ }^{26}$ According to the provisions of this law, the governors of the provinces of Egypt must respond within four months to inquiries regarding the building of new churches submitted to them by the Christian communities. In the event of a refusal, the governor must provide valid arguments to justify his decision, and the community that was refused is entitled to appeal to the administrative courts. The new law, among other things, states, "the size of the church should correspond to the number of citizens belonging to the Christian community and should take into account population growth".

The new law, despite its imperfection, is a step forward from the so-called "10 rules" added in 1934 to Ottoman legislation by the Egyptian Ministry of the Interior, which prohibited, among other things, the construction of new churches near schools, canals, government buildings, railways, and residential areas. In many cases, the strict application of these rules resulted in refusals to the requests and the prohibition of constructing churches in cities and villages inhabited mainly by Christians, especially in the rural areas of Upper Egypt.

The UK-based "Open Doors" NGO has been trying to help Christians around the world for over 60 years. This organization maintains a database of violations of the rights of Christians and the so-called "black list of states" where Christians are most discriminated

23 Among such NGOs are "Open Doors", "Aid to the Church in Need", “Christian Solidarity International”, "Observatoire de la Christianophobie", "Gatestone Institute", Catholic agency "Agenzia Fides", Protestant fund "Varnava" and "International Christian Concern", portal of the Church Scientific Center "Orthodox Encyclopedia" Sedmitsa.ru, "Blagovest-info" agency.

24 Extremist Persecution of Christians, Gatestone Institute. Available online: https://www.gatestoneinstitute.org/13312/pure-genocide (accessed on 20 December 2020).

25 La religion la plus persécutée au monde? Le christianisme (The most persecuted religion in the world?-Chrisitianity). Available online: http:/ / www.slate.fr/story/93959/christianisme\%20 (accessed on 20 December 2020); Christianity—the most persecuted religion. Available online: https://inosmi.ru/world/20141103/224051622.html (accessed on 20 December 2020).

26 Egyptian Parliament passed a law that facilitates the construction of new Christian churches in the country, Pravoslavie.By. Available online: http://www.pravoslavie.by/news/parlament-egipta-prinjal-zakon-oblegchajushij-stroitelstvo-novyh-hristianskih-hramov-v-strane (accessed on 20 December 2020). 
against. Thus, four African states are in the top ten: Somalia, Sudan, Eritrea, and Libya. ${ }^{27}$ Islamic terrorist groups operate in a number of African countries-for example, Boko Haram (in May 2014, the UN Security Council included it in the list of terrorist organizations).

From this perspective, the adoption on 12 February 2016 in Havana (Cuba) of a Joint Statement following the meeting between His Holiness Patriarch Kirill of Moscow and All Russia and His Holiness Pope Francis is of great importance. Paragraph 8 of the Joint Statement states the following:

"Our eyes are primarily fixed upon those regions of the world where Christians are being persecuted. In many countries in the Middle East and North Africa, the whole families, villages and cities of our brothers and sisters in Christ are being destroyed. Their temples are subjected to barbaric destruction and plundering, their shrines desecrated and their monuments-destroyed". ${ }^{28}$

Do not forget that the functions of NGOs are limited. It is extremely important to discuss this problem in the international arena within the framework of interstate or expert forums, so that states listen and pay attention to the oppression of Christians. For this, there are special international human rights mechanisms, which include UN human rights treaty bodies, Universal Periodic Review (UPR), special procedures under the UN Human Rights Council.

For instance, in 2015, a joint statement was adopted by 65 States $^{29}$ Supporting the Human Rights of Christians and Other Communities, particularly in the Middle East"30, which was pronounced at the initiative of the Russian Federation, Holy See, and Lebanon in the course of the 28th session of the UN Human Rights Council. Among other things, this Joint Statement called on all states of the world "to reaffirm their commitment to respect the rights of everyone, in particular the right to freedom of religion, which is enshrined in the fundamental international human rights instruments".

For example, in Sudan, Christians have been persecuted for many years. In 2014, a Sudanese court sentenced a pregnant woman who converted to Christianity to death by hanging, which sparked a new wave of controversy over the punishment for apostasy in the country. ${ }^{31}$ The international community is trying to combat these terrible phenomena in Sudan. Sudan has ratified the 1966 International Covenant on Civil and Political Rights, and the Human Rights Committee, after considering its periodic report in 2018, noted the following: On the one hand, the President of the Sudan granted amnesty to the Czech Christian activist Petr Jasek, who had been convicted of espionage, but on the other hand, expressed concern about restrictions, in law and practice, imposed upon the right to freedom of conscience and religious belief, including reports of the destruction of churches. For many years now, the international community has been asking Sudan to repeal Article 126 of the Criminal Code on the crime of apostasy. Although Sudan explains in response that in the entire history of law enforcement, there have only been four cases of prosecution

27 The Open Doors World Watch List is an in-depth record of the 50 countries where it is most difficult to live as a Christian, Open Doors. Available online: https:/ / www.opendoorsuk.org/persecution/countries/ (accessed on 20 December 2020).

28 Joint statement of Pope Francis and His Holiness Patriarch Kirill, 12 February 2016, Havana, Official website of the Moscow Patriarchate. Available online: http:/ / www.patriarchia.ru/db/text/4372074.html (accessed on 20 December 2020).

29 Joint statement by the Russian Federation, Holy See, Lebanon, Albania, Andorra, Argentina, Armenia, Australia, Austria, Belarus, Belgium, Bosnia and Herzegovina, Brazil, Bulgaria, Canada, the Czech Republic, Congo, Croatia, Cuba, Cyprus, Denmark, El Salvador, Estonia, Finland, France, Germany, Greece, Guatemala, Haiti, Honduras, Hungary, Iceland, Iraq, Ireland, Israel, Italy, Japan, Liechtenstein, Luxemburg, Macedonia, Mali, Malta, Monaco, Netherlands, Norway, Panama, Paraguay, Peru, Philippines, Poland, Portugal, the Republic of Korea, Romania, San Marino, Serbia, Slovakia, Slovenia, Somalia, Spain, Switzerland, Syria, the United Kingdom, the United States of America, Venezuela, Zambia.

30 Joint statement by 65 States "Supporting the Human Rights of Christians and Other Communities, particularly in the Middle East" pronounced at the initiative of the Russian Federation, Holy See and Lebanon in the course of the 28th UNHRC session, Geneva, 13 March 2015, Official website of the Ministry of Foreign Affairs of the Russian Federation. Available online: http:/ /www.mid.ru/foreign_policy/humanitarian_cooperation/-/ asset_publisher/bB3NYd16mBFC/content/id/1092273 (accessed on 20 December 2020); Joint Statement on "Supporting the Human Rights of Christians and Other Communities, particularly in the Middle East" at the 28th Session of the Human Rights Council, Geneva, 13 March 2015, Holy See Press Office website. Available online: https:/ / press.vatican.va/content/salastampa/it/bollettino/pubblico/2015/03/13/0186/00415.html (accessed on 20 December 2020).

31 Death Sentence in Sudan: apostasy controversy, 16 May 2014. Available online: https://www.bbc.com/russian/society/2014/05/140515_sudan_ death_penalty_apostasy (accessed on 20 December 2020). 
for apostasy and that only open proselytizing is criminalized; the Committee reiterates that such practices are incompatible with Articles 18-19 of the International Covenant on Human Rights and recommended to repeal article 126 of the Criminal Code and amend legislative provisions that violate freedom of thought, conscience, religion, and expression. Moreover, the UNHRC recommended that Sudan refrain from interfering in worship by persons who do not follow the official religion (Islam is the predominant religion at $90.7 \%$ of the population while Christianity forms $5.4 \%$ of the population) - for example, by destroying places of worship - if the interference is not based strictly on the requirements of necessity and proportionality. ${ }^{32}$

In this regard, it should be noted that 21 countries provide criminal responsibility for apostasy, and in 12 countries-Afghanistan, Brunei, Islamic Republic of Iran, Yemen, Qatar, Mauritania, Malaysia, Maldives, Nigeria, United Arab Emirates, Saudi Arabia, and Somalia-apostasy is punished, ultimately, with death penalty ${ }^{33}$.

However, on 14 December 2014, Reverend Yat Michael Ruot Puk, a pastor from the Southern Sudan Evangelical Church, was arrested by National Security Service officers. On 11 January 2015, Reverend Peter Yein Reith was arrested at his residence. Both clergymen were arrested without any arrest warrant and were held incommunicado until 1 March 2015. On 4 May 2015, they were brought before a court, where they were both charged with undermining the constitutional system, waging war against the state, espionage, unlawful disclosure and receipt of official information or documents, arousing feelings of discontent among regular forces, breach of public peace, and offenses relating to insulting religious beliefs. Following these charges and subsequent hearings on 19 and 31 May 2015, both pastors were allegedly moved to a high security prison in North Khartoum. They were last seen by their families and pastors from their church on 3 June $2015 .{ }^{34}$ This fact is in contravention of Articles 18, 19, and 20 of the Universal Declaration of Human Rights.

Such violations are not uncommon and are reported on an ongoing basis by the UN Independent Expert on the Human Rights Situation in the Sudan ${ }^{35}$, which keeps the situation under the constant control of the international community.

Moreover, in relation to Sudan, the UN Independent Expert ${ }^{36}$ received information about arrests and restrictions on freedom of religion or belief of members of Christian communities. ${ }^{37}$ The independent expert noted that he had received numerous complaints in relation to the conviction of Mariam Ibrahim on charges of apostasy. She was subsequently released from custody by the decision of the Court of Appeal. The independent expert urged Sudan to fully respect the right to freedom of religion without discrimination of any kind. $^{38}$

Moreover, the issues of discrimination against Christians in Sudan have been the subject of consideration in the regional African system of human rights protection. In 1999, the African Commission on Human and Peoples' Rights considered a lawsuit filed by the Association of Member Episcopal Conference in Eastern Africa for the oppression of Sudanese Christians and religious leaders; expulsion of all missionaries from Juba;

32 Human Rights Committee, Concluding observations on the fifth periodic report of the Sudan, UN Dosc. CCPR/C/SDN/CO/5, 19 November 2018, paras. 49-50. Available online: https://tbinternet.ohchr.org/_layouts/15/treatybodyexternal/Download.aspx?symbolno=CCPR/C/SDN/CO/ $5 \&$ Lang=En (accessed on 20 December 2020).

33 Humanists International. The Freedom of Thought Report 2019: Key Countries Edition. 2019. Available online: https:/ / fot.humanists.international/ download-the-report/ (accessed on 29 December 2020).

34 Report of the Independent Expert on the situation of human rights in the Sudan. A/HRC/30/60, paras, 30-31, 24 August 2015. Available online: https:/ / undocs.org/ru/A/HRC/30/60 (accessed on 20 December 2020).

35 Independent Expert on the situation of human rights in the Sudan. Available online: https://www.ohchr.org/EN/HRBodies/SP/ CountriesMandates/SD/Pages/IESudan.aspx (accessed on 20 December 2020).

36 Summary prepared by the Office of the United Nations High Commissioner for Human Rights in accordance with paragraph 15 (c) of the annex to Human Rights Council resolution 5/1 and paragraph 5 of the annex to Council resolution 16/21-Sudan. 2016, UN Doc. A/HRC/WG.6/25/SDN/2. Available online: https://digitallibrary.un.org/record/823938?ln=ru (accessed on 20 December 2020).

37 Report of the Independent Expert on the situation of human rights in the Sudan, Aristide Nononsi, 2015, UN Doc. A/HRC/30/60, par. 30. Available online: https: / / digitallibrary.un.org/record/804337 (accessed on 20 December 2020).

38 See Report of the Independent Expert on the situation of human rights in the Sudan, Mashood A. Baderin, 2014, UN Doc. A/HRC/27/69, paras. 29, 43. Available online: https: / / digitallibrary.un.org/record/780607? ln=ru (accessed on 20 December 2020). 
arbitrary arrests and detention of priests; the closure and destruction of Church buildings; the constant harassment of religious figures, and prevention of non-Muslims from receiving aid. $^{39}$

Investigations revealed that Christians were persecuted and forced to convert to Islam, prevented from preaching or building their churches, experienced limited freedom of expression in the national press, Christian clergy were subjected to harassment, arbitrary arrest, expulsion, and denial of access to work and food aid, and food distribution in prisons was not equal (Christian prisoners were blackmailed for food). Having considered all the evidence presented, the African Commission concluded that Sudan did not provide any evidence or excuses and, accordingly, violated Art. 8 of the 1981 African Charter on Human and Peoples' Rights that guarantees freedom of conscience and free exercise of religion (para. 76). ${ }^{40}$

Religious discrimination has been increasing over the last 15 years, but in interregional comparison, sub-Saharan Africa has a low level of discrimination. High levels of discrimination are embedded in problematic state-religion relations and existing cleavages become mobilized along religious lines through transnational influences and geography; see (Basedau and Schaefer-Kehnert 2019).

Religious violence is increasingly becoming a concern across sub-Saharan Africa. Failure to stem one can lead to the emergence of the other. While there may be several underlying factors in conflict or violence that do not have religious roots, the resulting divisions could forever alter Christian-Muslim and Muslim-Muslim relations. Currently, an effective response to address religious violence from secular states is lacking. The failure of international leaders of the Global North to understand African politics results in failed policies; see (Lado and Lynch 2014).

There are similar trends in the Middle East and Asia. Several mass killings by ISIS have targeted other religious groups in the Syrian Arab Republic, including Christians. More broadly, minority religious communities have been severely affected by the civil war in the Syrian Arab Republic, with the estimated Christian community declining from 360,000 in 2012 to 25,000 today $^{41}$.

Hmong Christians live mainly in the northern provinces of Vietnam, along the border with Laos and China. Their exact number is unknown. According to various estimates, it ranges from 120 thousand to 500 thousand people. In Vietnam, Hmong and Montagnar Christians cannot obtain the necessary registration documents for citizenship.

In accordance with the principles of international humanitarian law, places of worship are under special protection during armed conflicts. Deliberate attacks on such objects are a war crime. For example, Jurgen Strup, who blew up a synagogue in Warsaw during World War II, was sentenced to death by the Warsaw Regional Court several years after the war. It is not always possible to bring to justice those responsible for committing such crimes. After the NATO war against Yugoslavia and the transfer of Kosovo and Metohija under the control of NATO troops, local Albanians began to destroy Serbian religious and cultural sites throughout the province. According to the letter of the Patriarch of the Serbian Orthodox Church Pavel from 2002 to the Special Representative of the UN Secretary General in Kosovo, Michael Steiner, and the Commander-in-Chief of the International Peacekeeping Forces in Kosovo (KFOR), General Marcel Valentin, after the peacekeepers entered Kosovo, the local Albanians destroyed more than 120 Orthodox churches, some of which were of medieval origin and part of the world cultural heritage (Guskova 2001).

According to Art. 8 (2) (e) (iv) of the Rome Statute, on the basis of which the International Criminal Court operates, one of the types of war crimes is "intentionally directing

39 Amnesty International, Comité Loosli Bachelard, Lawyers' Committee for Human Rights, Association of Members of the Episcopal Conference of East Africa, Sudan. Available online: https:/ / www.achpr.org/sessions/descions?id=106 (accessed on 20 December 2020).

40 Ibid.

41 See Bishop of Truro's Independent Review for the Foreign Secretary of FCO Support for Persecuted Christian. Available online: https:// christianpersecutionreview.org.uk/report/ (accessed on 20 December 2020). 
attacks against buildings dedicated to religion, education, art, science or charitable purposes, historic monuments, hospitals and places where the sick and wounded are collected, provided they are not military objectives". ${ }^{42}$

The UN Secretary General presented the United Nations Plan of Action to Safeguard Religious Sites in September 2019. ${ }^{43}$ The plan was developed under the leadership of the High Representative of the Alliance of Civilizations in close collaboration with governments, religious organizations, civil society, and the private sector. The document contains specific recommendations for the protection of religious sites and the promotion of values such as tolerance and compassion.

\section{Conclusions}

Over the past 75 years, an independent branch has been formed within the framework of international law-international human rights law-which is based on the principle of respect for human rights and fundamental freedoms, including freedom of thought, conscience, and religion; a significant international legal framework has been created that guarantees the observance of the rights to freedom of conscience, thought, and religion; systems of statutory and treaty control mechanisms at the UN level have been developed and are operating, as well as similar regional structures, within the framework of which states report on the fulfillment of their obligations to implement the right to freedom of thought, conscience, and religion and are responsible in case of violations of the rights of specific individuals. However, despite all these important achievements of modern international law, the problem of Christians exercising their right to freedom of thought, conscience, and religion is acute in many countries of the world.

The term "Christianophobia" is widely used in the international arena. All types of discriminatory violations by states of the right of Christians to freedom of conscience, thought, and religion can be basically divided into direct discrimination (persecution, prosecution) and indirect discrimination (when seemingly neutral norms actually exclude Christians from entire spheres of professional activity).

We show that the absence of a fight against discrimination against Christians in the Global North leads to the spread of this phenomenon in the Global South.

As follows from the conducted research, in a number of countries of the Global South, Christians continue to be persecuted and killed just because they are Christians. Sudan is a prime example.

In other countries of the Global South, which largely follow the practice of the countries of the Global North, Christians are not killed for their faith but are deprived of their right to work, just because they want not only to remain Christians by name but also to be guided by their conscience in their actions, including at the workplace and in the performance of professional duties. Moreover, this happens under various kinds of "apologetic" pretexts. Thus, the right to life, the right to private life of a woman, which includes the "right to abortion," is placed unequivocally higher than the right to life of an unborn child. If Christian healthcare providers are not willing to accept this, they commit themselves to abandoning their medical practice in the field of obstetrics. Active propaganda and promotion of the so-called "LGBT rights" result in discrimination against Christians when they are forced to participate in what they consider to be evil and sin. If they refuse, they are subject to sanctions up to a dismissal and a fine. At the same time, human rights bodies are substituting concepts in the analysis of discrimination, absolutizing and looking for remedies for the "right to abortion" and "LGBT rights" instead of analyzing different treatment of people with and without Christian convictions.

This trend can be clearly seen in the practice of the Council of Europe, followed by a number of countries in the Global South. On the one hand, the member states of the

42 Rome Statute of the International Criminal Court (Rome, 17 July 1998). Available online: https:/ / www.icc-cpi.int/resource-library/documents/rseng.pdf (accessed on 20 December 2020).

43 The United Nations Plan of Action to Safeguard Religious Sites. Available online: https://www.un.org/sg/sites/www.un.org.sg/files/atoms/files/ 12-09-2019-UNAOC-PoA-Religious-Sites.pdf (accessed on 20 December 2020). 
Council of Europe try to provide additional guarantees to religious minorities. On the other hand, the ECHR takes the directly opposite position, refusing to practice its religion not to a religious minority but to a religious majority, in order to protect the so-called "rights" of persons with a non-traditional orientation and in those cases where discrimination against these persons is in fact absent.

It is extremely important to discuss problems of discrimination of Christians in the Global South at the international arena within the framework of interstate or expert forums so that states listen and pay attention to the oppression of Christians. For this, there are special international human rights mechanisms, which include UN human rights treaty bodies, Universal Periodic Review (UPR), special procedures under the UN Human Rights Council.

In order to counteract the above phenomena, it seems important to implement a whole range of measures: to abolish laws that undermine the exercise of the human right to freedom of religion or belief, including the withdrawal of reservations to international human rights treaties that are incompatible with freedom of religion or belief; introduce principles of universality, non-discrimination, and equality, participatory decision-making methodology, the obligation to ensure accountability, and the recognition of the interdependence of rights in policymaking; take steps to empower religious minorities so that they can claim the exercise of all their human rights and fundamental freedoms; enact comprehensive anti-discrimination legislation prohibiting direct and indirect discrimination, harassment, and lack of reasonable accommodation based on religion and all other grounds recognized in international law and in all areas of life regulated by law.

It seems that both direct and indirect discrimination on the basis of religion is unacceptable in democratic rule-of-law states of the 21st century. States are obliged to stand up for Christians, reaffirming by deeds the interrelation and indivisibility of all human rights.

Author Contributions: Conceptualization, N.S.S., E.V.K. and A.M.S.; Methodology, N.S.S., E.V.K. and A.M.S.; Validation, N.S.S., E.V.K. and A.M.S.; Formal Analysis, N.S.S., E.V.K. and A.M.S.; Investigation, N.S.S., E.V.K. and A.M.S.; Resources, N.S.S., E.V.K. and A.M.S.; Data Curation, N.S.S., E.V.K. and A.M.S.; Writing-Original Draft Preparation of Section 2, E.V.K., of Section 3, N.S.S., of Section 4, A.M.S.; Writing-Review \& Editing, N.S.S., E.V.K. and A.M.S.; Project Administration, N.S.S.; Funding Acquisition, N.S.S. All authors have read and agreed to the published version of the manuscript.

Funding: This research was funded by the Russian Foundation for Basic Research, grant number 18-011-00292.

Institutional Review Board Statement: Not applicable.

Informed Consent Statement: Not applicable.

Data Availability Statement: Not applicable.

Conflicts of Interest: The authors declare no conflict of interest.

\section{References}

Abashidze, Aslan Kh., and Andrei A. Klishas. 2015. “Gender aspects" and "traditional values" through the prism of international human rights law. In Gender Aspects and Traditional Values in the Light of International Law: Materials of Round Tables on 12 April and 10 October 2014 in within the Framework of the XII Annual International Scientific-Practical Conference "Actual Problems of Modern International Law" Dedicated to the Memory of Professor I. P. Blishchenko. Edited by A. Kh. Abashidze, N. S. Semenova, E. V. Kiseleva and E. S. Alisievich. Moscow: Pokrov PRO, pp. 131-42.

Basedau, Matthias, and Johanna Schaefer-Kehnert. 2019. Religious discrimination and religious armed conflict in sub-Saharan Africa: An obvious relationship? Religion, State and Society 47: 30-47. [CrossRef]

Billingham, Rupert E., Leslie Brent, and Peter B. Medawar. 1953. "Actively acquired tolerance" of foreign cells. Nature 172: 603-6. [CrossRef] [PubMed]

Chavkin, Wendy, Laurel Swerdlow, and Jocelyn Fifield. 2017. Regulation of Conscientious Objection to Abortion: An International Comparative Multiple-Case Study. Health and Human Rights Journal 19: 55-68. 
Council of Europe: European Court of Human Rights. 2016. Guide on Article 8 of the European Convention on Human Rights-Right to Respect for Private and Family Life. December 31. Available online: https://www.refworld.org/docid/5a016ebe4.html (accessed on 20 December 2020).

Disney, Lindsey, and Larry Poston. 2010. The Breath of Life: Christian Perspectives on Conception and Ensoulment. Bible E Religion Educator Scholarship 7: 271-95.

Domenici, Irene. 2020. Antigone Betrayed? The European Court of Human Rights' Decisions on Conscientious Objection to Abortion in the Cases of Grimmark v. Sweden and Steen v. Sweden. European Journal of Health Law 1: 1-22. [CrossRef]

European Commission of Human Rights. 1980. The Case of W.P. v. the United Kingdom. Available online: http:/ / hudoc.echr.coe.int/ app/conversion/pdf/?library=ECHR\&id=001-74270\&filename=001-74270.pdf (accessed on 5 February 2021).

European Commission of Human Rights. 1989. The Case of Rommelfanger v. FRG. Available online: http://hudoc.echr.coe.int/ webservices/content/pdf/001-1010?TID=thkbhnilzk (accessed on 5 February 2021).

European Court of Human Rights. 2004. The Case of Vo v. France. Available online: https:/ /hudoc.echr.coe.int/app/conversion/pdf/ ?library=ECHR\&id=003-1047783-1084371\&filename=003-1047783-1084371.pdf (accessed on 5 February 2021).

European Court of Human Rights. 2007. The Case of Tysiac v. Poland. Available online: https://www.refworld.org/cases,ECHR,4703 76112.html (accessed on 5 February 2021).

European Court of Human Rights. 2010. The Case of A.B. and C v. Ireland. Available online: https://hudoc.echr.coe.int/app/ conversion/pdf/?library=ECHR\&id=001-102332\&filename=001-102332.pdf (accessed on 5 February 2021).

European Court of Human Rights. 2011. The Case of R.R. v. Poland. Available online: https://hudoc.echr.coe.int/fre\# \\{\%22itemid\%22: $[\% 22001-104911 \% 22] \backslash\}$ (accessed on 5 February 2021).

European Court of Human Rights. 2013. The Case of Eweida and Others v. United Kingdom. Available online: https:/ /hudoc.echr.coe. int/eng\#\\{\%22itemid\%22:[\%22001-115881\%22] \} (accessed on 20 December 2020).

European Court of Human Rights. 2020a. The Case of Ellinor Grimmark v. Sweden. Available online: https://hudoc.echr.coe.int/eng\# $\backslash\{\% 22$ itemid\%22:[\%22001-201915\%22] $\}$ (accessed on 20 December 2020).

European Court of Human Rights. 2020b. The Case of Linda Steen v. Sweden. Available online: https://hudoc.echr.coe.int/eng\#\\{\%2 2itemid\%22:[\%22001-201732\%22] \\} (accessed on 20 December 2020).

Fundamentals of the Social Concept of the Russian Orthodox Church. 2008. June 9. Available online: http:/ / www.patriarchia.ru/db/ text/419128.html (accessed on 1 February 2021).

Guskova, Elena. 2001. History of the Yugoslav Crisis (1990-2000). Moscow: Russian law/Russian National Fund. (In Russian)

Humanae Vitae. 1968. Encyclical Letter of the Supreme Pontiff Paul VI. July 25. Available online: http:/ / www.vatican.va/content/ paul-vi/en/encyclicals/documents/hf_p-vi_enc_25071968_humanae-vitae.html (accessed on 1 February 2021).

Lado, Ludovic, and Tiffany Lynch. 2014. Religious Violence in Sub-Saharan Africa and the Future of the Secular State. Available online: https:/ / www.wilsoncenter.org/event/religious-violence-sub-saharan-africa-and-the-future-the-secular-state-0 (accessed on 20 December 2020).

Ling, John R. 2017. When Does Human Life Begin? Christian Thinking and Contemporary Opposition. Newcastle upon Tyne: The Christian Institute, Available online: https://www.christian.org.uk/wp-content/uploads/when-does-human-life-begin.pdf (accessed on 23 January 2021).

Melton, J. Gordon, and Martin Baumann. 2010. Religious Adherents of the World by Continent and Region. In Religions of the World: A Comprehensive Encyclopedia of Beliefs and Practices. Santa Barbara, Denver and Oxford: ABC-CLIO.

Murdoch, Jim. 2012. Protecting the Right to Freedom of Thought, Conscience and Religion under the European Convention on Human Rights. Council of Europe Human Rights Handbooks Series; Strasbourg: Council of Europe.

Puppinck, Grégor. 2013. Abortion and the European Convention on Human Rights. Irish Journal of Legal Studies 3: 142-93. Available online: https: / / ssrn.com/abstract=2320539 (accessed on 23 January 2021).

Schlesinger, Kira. 2017. Pro-Choice and Christian: Reconciling Faith, Politics, and Justice. Louisville Kentucky: Westminster John Knox Press.

Semenova, Nataliya S. 2014. International legal protection of traditional values: Implementation of the right to education. Observer 7: 34-43. (In Russian).

Semenova, Nataliya S. 2019. The Law of God-The moral basis of law. Praxis 1: 28-36. (In Russian).

Semenova, Nataliya S., and Ekaterina V. Kiseleva, eds. 2017. Protection of Traditional Values and International law: Monograph. Moscow: Pokrov PRO Publ. (In Russian)

St. John Chrysostom. n.d. Homilies on the Epistle to the Romans. Available online: https://www.documentacatholicaomnia.eu/03d/ 0345-0407,_Iohannes_Chrysostomus,_Homilies_on_The_Epistle_To_The_Romans,_EN.pdf (accessed on 20 January 2021).

United Nations Committee on Economic, Social and Cultural Rights. 2016. General Comment No. 22 (2016) on the Right to Sexual and Reproductive Health (Article 12 of the 1966 International Covenant on Economic, Social and Cultural Rights). May 2. Available online: https: / / digitallibrary.un.org/record/832961 (accessed on 20 December 2020).

United Nations Committee on Economic, Social and Cultural Rights. 2017. General comment No. 24 (2017) on State obligations under the International Covenant on Economic, Social and Cultural Rights in the Context of Business Activities. August 10. Available online: https: / / www.refworld.org/docid/5beaecba4.html (accessed on 2 February 2021).

United Nations Human Rights Committee. 1993. General Comment No. 22: Article 18 (Freedom of Thought, Conscience or Religion). July 30. Available online: https:// www.refworld.org/docid/453883fb22.html (accessed on 1 February 2021). 
United Nations Human Rights Committee. 2000. General Comment No. 28 (2000) on Article 3 (The Equality of Rights Between Men and Women). March 29. Available online: https://www.refworld.org/docid/45139c9b4.html (accessed on 1 February 2021).

United Nations Human Rights Committee. 2018. General Comment No. 36 (2018) on the Right to Life. Available online: https: //www.refworld.org/publisher,HRC,GENERAL, 5e5e75e04,0.html (accessed on 20 December 2020).

Vasiliev, Alexei M., ed. 2010. Africa: Encyclopedia. In Two Volumes. Moscow: Infra-M Publ, vol. 2. (In Russian) 